Original Research Paper

\title{
Penerapan Green Campus Melalui Kegiatan Redesain Taman di Lingkungan LPPM Universitas Mataram
}

\begin{abstract}
Ahmad Jupri $^{*}$, Dwi Rina Isbandiyah², Zaenun Niswati ${ }^{3}$ I Made Artha Sudanta', Yohanes Mulyono², Muhamad Fajrin Akbar ${ }^{4}$, Cahya Indra Lesmana ${ }^{1}$, Anisa Uswatun $\mathbf{H}^{3}$, Elita Akhsani ${ }^{3}$, Moh Rizal Efendi ${ }^{5}$, Aldi Dwi Cahya ${ }^{5}$
\end{abstract}

${ }^{I}$ Fakultas Matematika dan Ilmu Pengetahuan Alam, Universitas Mataram

${ }^{2}$ Fakultas Hukum, Universitas Mataram

${ }^{3}$ Fakultas Pertanian, Universitas Mataram

${ }^{4}$ Fakultas Teknik, Universitas Mataram

${ }^{5}$ Fakultas Ilmu Sosial dan Ilmu Politik, Universitas Mataram

DOI: https://doi.org/10.29303/jpmpi.v4i2.811

Sitasi: Jupri, A., Isbandiyah, D. R., Niswati, K., Sudanta, I. M. A., Mulyono, Y., Akbar, M. F., Lesmana, C. I., Uswatun, A., Akhsani, E., Efendi, M. R., \& Cahya, A. C. (2021). Penerapan Green Campus Melalui Kegiatan Redesain Taman di Lingkungan LPPM Universitas Mataram. Jurnal Pengabdian Magister Pendidikan IPA, 4(2)

Article history

Received: 23 Maret 2021

Revised: 20 Mei 2021

Accepted: 22 Juni 2021

*Corresponding Author:

Ahmad Jupri, Fakultas

Matematika dan Ilmu

Pengetahuan Alam, Universitas

Mataram;

Email: juprizikril@gmail.com

\begin{abstract}
Pelestarian lingkungan merupakan hal penting dalam kehidupan manusia. Pelestarian lingkungan dilakukan dengan memanfaatkan lingkungan secara bijak agar keseimbangan lingkungan tetap terjaga. Hubungan antara manusia dan lingkungan hidup merupakan hubungan yang sangat penting bagi generasi sekarang dan generasi yang akan datang. KKN Era New Normal Green Campus merupakan salah satu kegiatan KKN yang berperan dalam pelestarian lingkungan dilingkungan Universitas Mataram serta dalam masyarakat. Green Campus merupakan upaya dalam mewujudkan pelestarian lingkungan dalam lingkungan kampus dengan melibatkan seluruh dosen, mahasiswa, petugas dan karyawan dalam lingkungan kampus. Di harapkan dengan Green Campus dapat meningkatkan perbaikan lingkungan dan kesadaran terhadap kepedulian lingkungan.
\end{abstract}

Keywords: Pelestarian Lingkungan Hidup; KKN New Normal; Green Campus.

hayati yang berada di hutan bermanfaat dan berperan penting dalam keseimbangan lingkungan hidup.

Indonesia juga dikenal sebagai negara maritim. Sebagian besar wilayah Indonesia terdiri dari lautan. Lautan di wilayah Indonesia kaya berbagai jenis ikan. Sumber daya alam laut berupa biota laut, tambang minyak lepas pantai dan pasir besi. Potensi ikan laut Indonesia mencapai 6 juta ton per tahun. Potensi laut Indonesia berada di urutan keempat pada 2009 di dunia. Seiring berjalannya waktu dan meningkatnya populasi manusia di bumi banyak terjadinya kerusakan alam pun tak dapat dipungkiri. Kerusakan alam seperti kebakaran hutan, pencemaran limbah kesungai atau mesia sangat besar, mencakup kayu dan semua makhluk yang mendiami hutan. Keanekaragaman 
laut, kerusakan ekosistem dan habitat flora dan fauna, serta berkurangnya populasi flora dan fauna tertentu, pencemaran udara, dan lain sebagainya.

Kerusakan alam sangat erat kaitannya dengan kerusakan lingkungan yang disebabkan dari kebiasaan-kebiasaan hidup manusia. Untuk menjaga alam kita juga harus berperan dalam menjaga lingkungan dimanapun kita berada. Di Indonesia, sejumlah persoalan lingkungan masih menjadi pekerjaan rumah yang membutuhkan penyelesaian. Persoalan ini menjadi sangat krusial karena menyangkut kualitas kehidupan di masa datang dan untuk generasi mendatang. Hal seperti kebiasaan masyarakat seperti membuang sampah sembarang yang dapat mengakibatkan bencana banjir, pencemaran air, pencemaran tanah, menyebabkan bakteri penyakit masih sangat sering dilakukan. Pelestarian lingkungan harus dimulai dari sekarang oleh setiap individu manusia dimanapun berada. Oleh karena itu untuk menjaga alam dan lingkungan Universitas Mataram khususnya LPPM berupaya dalam menerapkan Green Campus di area lingkungan Universitas Mataram.

Green Campus atau program kampus hijau adalah program untuk mengupayakan pelestarian lingkungan dan pemanfatan sumber daya alam pada lingkungan kampus yang dilakukan oleh seluruh masyrakat dan khususnya civitas akademika. Pengelolaan kampus secara terus menerus dan berkesinambungan dengan memperhatikan lingkungan merupakan keharusan dan hal yang sangat penting saat ini. Green Campus di Universitas Mataram ini dilaksanakan untuk menyelesaikan masalah lingkungan yang terdapat pada Lembaga Penelitan Dan Pengabdian Masyarakat.

Adapun Beberapa masalah lingkungan yang ditemukan di LPPM yaitu: 1. Kondisi lingkungan di LPPM yang masih belum terawat dengan baik, sehingga banyak sumber daya alam yang tidak dimanfaatkan dengan baik. 2. Kondisi Taman di Lingkungan LPPM tidak terawat dengan baik, banyak tanaman hias yang berada di taman tersebut tidak tumbuh dengan baik, kolam ikan yang sudah tidak difungsikan, sehingga perlu dilakukan redesain taman.

Program Green Campus ini bertujuan untuk menyelesaikan permasalahan lingkungan dan menciptakan kampus yang sehat dan peduli dengan lingkungan dengan melakukan pengelolaan lingkungan secara sistematis dan terus-menerus. Manfaat Green campus tidak lain adalah untuk menambah wawasan tentang pelestarian lingkungan, memberikan rasa nyaman, bersih, sehat dan asri dalam menjalankan aktivitas di lingkungan kampus serta ikut aktif secara nyata dalam pelestarian lingkungan.

\section{Metode}

Metode pelaksanan yang digunakan dalam pelaksanaan Green Campus ini dilakukan dengan tahapan antara lain:

(1) Melakukan surevy lokasi LPPM di Universitas Mataram.

(2) Mencatat permasalahan lingkungan yang ditemukan di LPPM Universitas Mataram,

(3) Menyusun rencana Green Campus yang tepat bagi permasalahan lingkungan yang telah ditemukan,

(4) Mempersiapkan alat dan bahan untuk program Green Campus yang sudah direncanakan,

(5) Menerapkan rencana Green Campus untuk penyelesaian permasalahan lingkungan,

(6) Evaluasi seluruh program Green Campus yang telah dilaksanakan.

Alat dan bahan yang diperlukan antara lain:

- Cangkul,

- Cepang

- Cat

- Kuas cat

- Ember

- Sikat

- Sapu lidi

- Selang air

- Bibit bunga hias

Pengumpulan data dalam program Green Campus ini dilakukan dengan observasi dan dokumentasi.

\section{Hasil dan Pembahasan}

Kondisi lingkungan LPPM sangatlah subur dan lembap di buktikan dengan banyaknya tumbuhan yang hidup dan dapat ditemukan di lokasi antara lain:

- Daun pegagan

- Pohon jati

- Pohon ketapang

- Tanaman lidah mertua

- Bunga kamboja

- Bunga kertas dan sebagainya 
Pada lokasi ditemukan juga berbagai masalah seperti sampah dan begitu banyak rumput liat, tumbuhan tidak terawat dan taman yang yang tidak berfungsi sebagaimana mestinya.

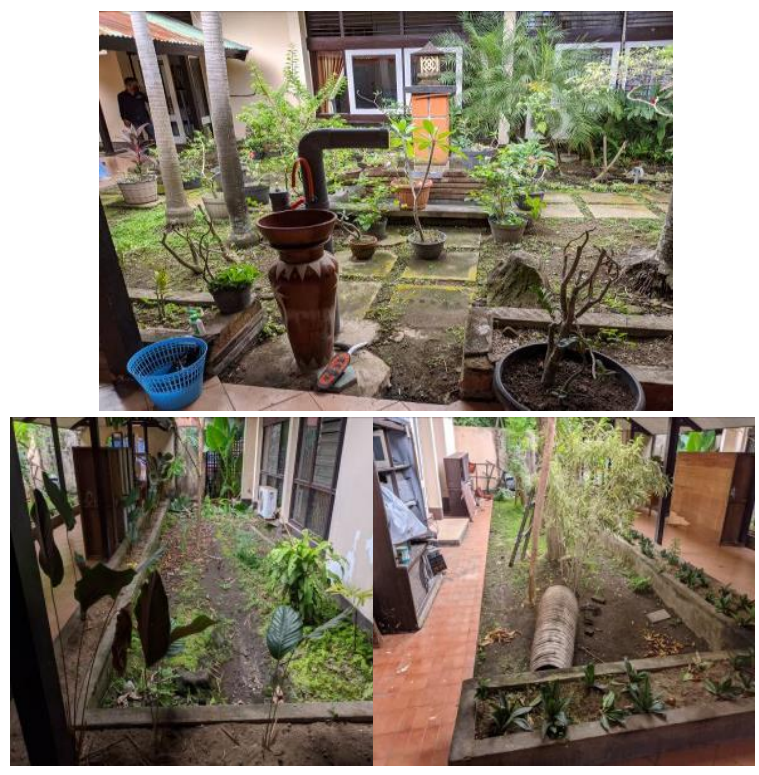

Program Green Campus yang akan diterapkan sesuai kondisi LPPM setelah survey lokasi ialah redesain taman. Redesain ialah kegiatan perencanaan dan perancangan kembali suatu perubahan fisik tanpa merubah fungsinya baik melalui perluasan maupun pemindahan lokasi. Redesain taman di lokasi LPPM dilakukan dengan tahapan sebgai berikut:

1. Membersihkan taman dengan memungut sampah mencabut rumput dan tumbuhan liar yang hidup tidak beraturan dan menyapu hingga bersih.

2. Menanam dan menata kembali tanaman hias di potpot yang tersedia ditaman, memotong tanaman yang bentuknya tidak teratur, mengganti beberapa tanaman dengan tanaman bunga hias menanam rumput hias.

3. Membersihkan dinding taman dan pot-pot dengan menyikat bagian yang berlumut dan bertanah.

4. Mengecat pot-pot ditaman dengan warna baru dan dinding dinding taman.

5. Mengecat kembali kolam yang ada dia area taman dan membuat kolam berfungsi kembali dengan mengisi kembali kolam ikan

6. Menyiram dan merawat tanaman yang telah ditanam hasil dari penerapan program Green Campus di Lembaga Penelitian dan Pengabdian Masyarakat Universitas Mataram dengan redesain taman.
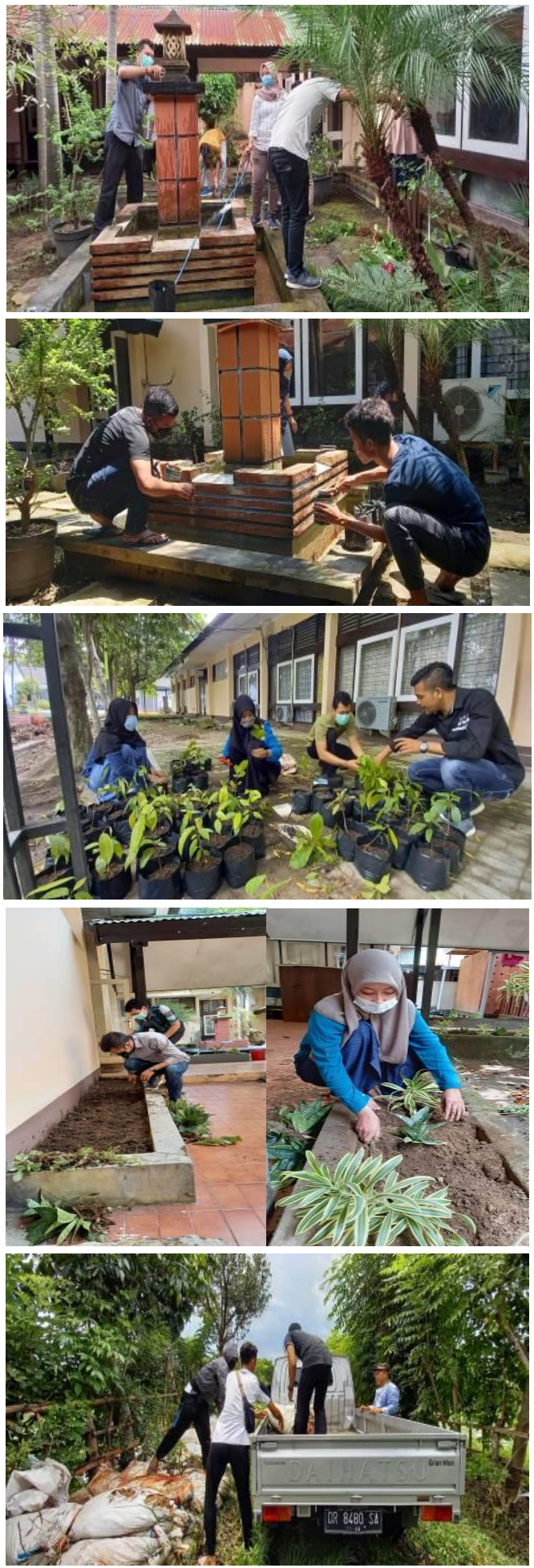

Redesain taman dilakukan secara bertahap pada taman bagian luar dan dalam. Pengerjaan redesain taman dilakukan selama 40 hari. Pemantauan dan perawatan pada tanaman baru dilakukan setiap hari dengan memperhatikan tumbuh kembang dari tanaman dan tumbuhan ditaman. 
Biaya dalam redesain taman sebesar Rp 326.000,dalam pembelian alat dan bahan antara lain:

- 1 liter cat abu= Rp. 110.000,-

- 1 tabung ukuran kecil cat merah bata= Rp. 30.000,-

- 1 tabung ukuran kecil cat warna hitam= Rp. 30.000,- 7 kuas cat = Rp. 126.000,-

- 1 sikat besi= Rp. 30.000,-

Dari penerapan Green Campus dengan redesain taman ini didapatkan hasil taman yang lebih indah dan hijau yang berfungsi kembali untuk memperindah lingkungan di LPPM.

\section{Kesimpulan}

Lingkungan LPPM masih belum terjaga dan terawat dengan baik. Potensi alam yang ada di lokasi belum dimanfaatkan dengan baik. Masih rendahnya kesadaran masyarakat kampus dalam mnjaga dan melestarikan lingkungan sekitarnya. Penerapan redesain taman yang paling tepat untuk LPPM. Redesain taman atau membuat taman berfungsi kembali pada LPPM dapat menghidupkan suasana yang asri dan indah pada lingkungan LPPM dan memberi kenyamanan bagi para karyawan dan mahasiswa di Universitas Mataram. Taman di area LPPM juga menambah nilai estetik dan ruang hijau pada bangunan.

\section{Daftar Pustaka}

Putri, Arum Sustrisni. 2020. "Potensi Kemaritiman Indonesia: Perikanan", https://www.google. com/amp/s/amp.kompas.com/skola/read/20 20/06/17/163000769/potensi-kemaritimanindonesia-perikanan, diakses pada 24 Maret pukul 10.44 WITA.

Putri, Arum Sustrisni. 2020. "Potensi Sumber Daya Alam Hutan", https://www.google.com/amp /s/amp.kompas.com/skola/read/2020/05/28/ 130000869/potensi-sumber-daya-alamhutan, diakses pada 24 Maret pukul 10.50 WITA. 